\title{
MARGINALIZOVANÍ BOHOVIA? PRÍSPEVOK K NÁBOŽENSKEJ IKONOGRAFII V STARŠEJ DOBE BRONZOVEJ
}

\author{
Pavol Jelínek* \\ *Slovenské národné múzeum-Archeologické múzeum, Žiž̌kova 12, 81006 Bratislava, Slovenské republika, pavol.jelinek@gmail.com
}

\begin{abstract}
Marginalized Gods? Contribution to Religious Iconography in Early Bronze Age. Until recently no anthropomorphic depictions from the Early Bronze Age were known in the western part of the Carpathian Basin and Central Danube Region. The author is presenting the recognized depictions, structured into typical iconographies. It is interesting that they are depictions of women. According to the results of comparative Indo-European studies the pantheons of the Early Bronze Age religions should be headed by male deities. The author reflects on different results of archaeology and religious studies. The answer apparently lies in the holistic study of human creativity.
\end{abstract}

Keywords: Early Bronze Age, religious iconographies, male and female deities

Abstrakt: V staršej dobe bronzovej neboli donedávna v západnej časti Karpatskej kotliny a strednom Podunajsku známe antropomorfné zobrazenia. Autor prezentuje rozpoznané zobrazenia, štruktúrované do typických ikonografií. Je zaujímavé, že ide o zobrazenia žien. Podl’a výsledkov komparatívnej indoeuropeistiky by panteóny starobronzových náboženstiev mali mat' na svojom čele mužské božstvá. Autor sa zamýšla nad rozdielnymi výsledkami archeológie a religionistiky. Odpoved' zrejme spočíva v holistickom štúdiu l'udskej tvorivosti.

Kl'účové slová: staršia doba bronzová, náboženské ikonografie, mužské a ženské božstvá

https://doi.org/10.46283/musarch.2020.1.02

\section{1. Úvod}

V texte sa stručne zaoberám niekol'kými otázkami, ktoré sa objavili pri štúdiu nedávno zverejneného fenoménu l’udských zobrazení zo staršej doby bronzovej (Jelínek - Valent 2019), ktoré považujeme za náboženské ikonografie. Väčšinou ide, s výnimkou samostatnej plastiky, o málo frekventované a v odbornej literatúre zriedkavo pertraktované, alebo doteraz nerozpoznané nálezy. Snád’ aj preto, že aj v dnešnej dobe ide o záležitost’ nadstavby (v marxistickom zmysle), ostáva problematika výskumu pravekého náboženstva u nás marginalizovaná.

\section{Ikonografie, popis, materiál}

Zo staršej doby bronzovej sú z východnej časti Karpatskej kotliny známe antropomorfné plastiky. Vd’aka zobrazeniam poprsia a/alebo náhrdelníkov vieme, že ide o zobrazenia žien. V západnej časti sa plastiky nevyskytujú. L’udské zobrazenia sa však vyskytujú na ženskej prestížnej plechovej industrii, akou sú bronzové čelenky, diadémy, a plechové klobúky. Poznáme ich napr. z Unína, Mušova, Melku, Franzhausenu a d’alších (Jelínek - Valent 2019, 49nn. s literatúrou; Leeb 1994, Abb. 8: 2; Abb. 10:11). Zhotovené sú technikou vybíjaného perlovca do bronzového plechu. 


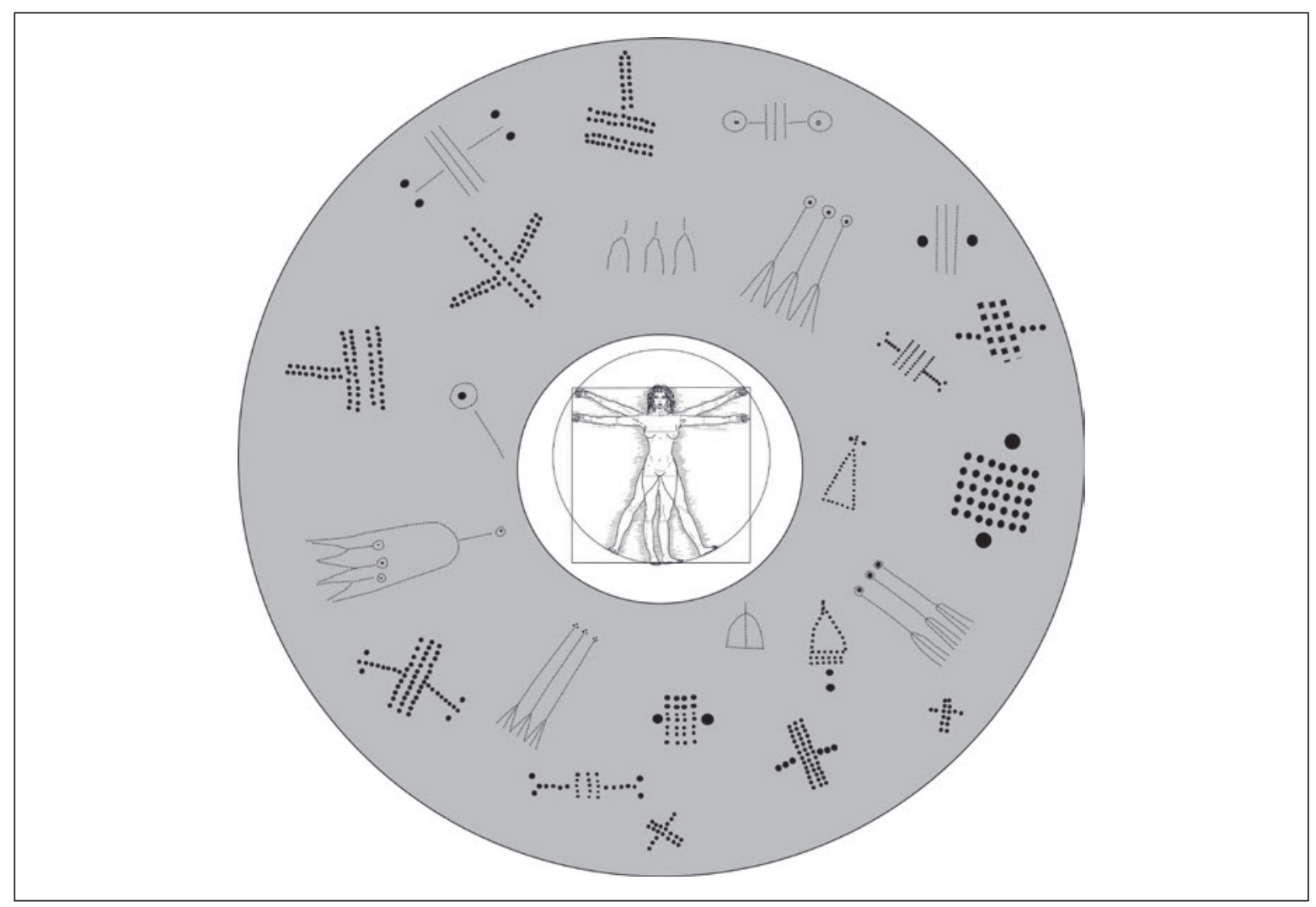

Obr. 1. Štylizované l’udské postavy na plechovej industrii zo staršej doby bronzovej (podl’a Jelínek - Valent 2019) a miera ich abstrakcie oproti reálnemu zobrazeniu v strede.

Fig. 1. Stylised human figures on metal industry from the Early Bronze Age and the degree of abstraction (after Jelinek - Valent 2019) in comparison with the real depiction in the centre.

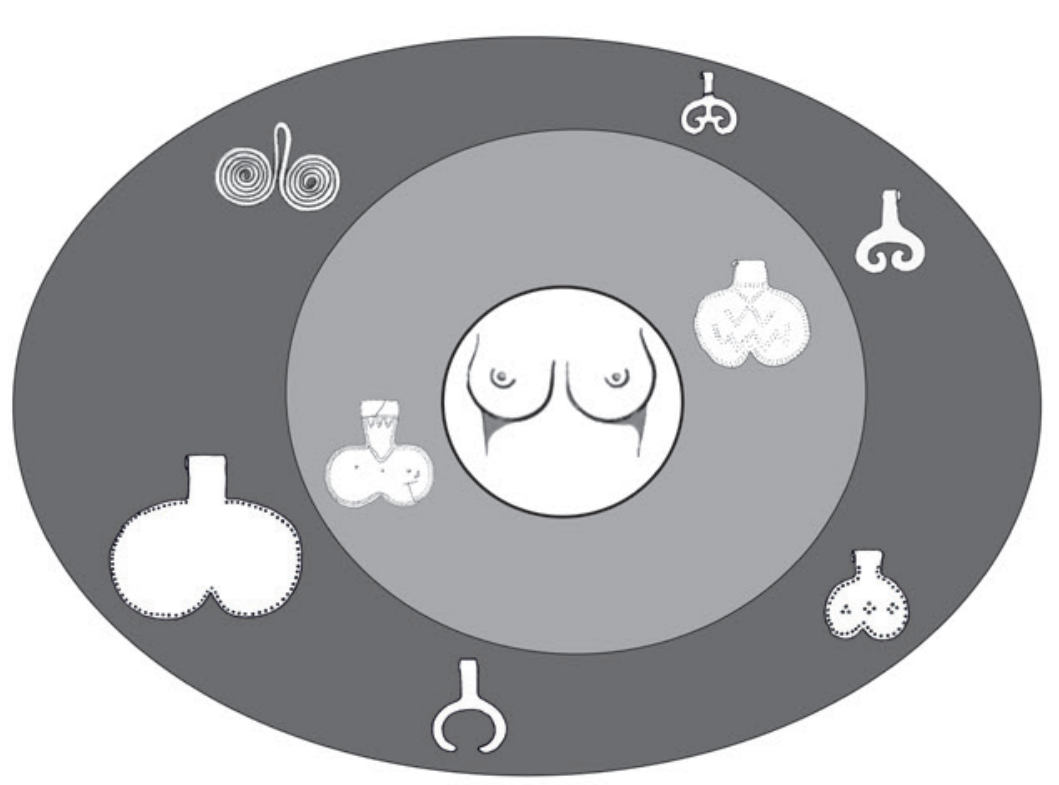

Obr. 2. Typy gynekomastonomorfných záveskov a stupne ich abstrakcie oproti reálnemu zobrazeniu v strede (podla Jelinek - Valent 2019).

Fig. 2. Types of gynecomastonomorphic pendants and degrees of abstraction in comparison with real depiction in the centre (after Jelinek - Valent 2019). 
Stupeň štylizácie postáv je mimoriadne vysoký (obr. 1). Časté sú v triadickom alebo párovom zobrazení.

Triády na diadémoch sú otočené o $90^{\circ}$. Postavy sú štylizované na hranicu rozpoznania: hlavy sú tvorené rozetou, telo zobrazuje dlhá línia, postava je ukončená dvomi ramenami, ktoré vybiehajú z drieku a vytvárajúcu trojuholníkovitú základňu - suknicu. Triády trojuholníkových postavičiek je možné nájst' aj vyryté na keramike.

Na klobúkoch a čelenkách sú stvárnené postavy rozmanitejšie. Ako ženské je s istotou možné rozpoznat’ trojuholníkovité postavy. Ďalšie, založené na jednoduchých zväzkoch línií s priečnymi ramenami/rukami, neposkytujú v otázke pohlavia tol'ko istoty, pripomínajú však adorujúce ženské postavy z inkrustovanej výzdoby na zadunajských urnách alebo antropomorfné ihlice z Bavorska (Jelínek - Valent 2019, 61). Ich „ženskost'“ je postavená práve na ich triadickej kompozícii. Ženské triády sú typické pre indoeurópske náboženstvá (Jelínek - Valent 2019, 66).

Ďalšiu skupinu antropomorfných ikonografií predstavujú bronzové závesky, s rôznym stupňom štylizácie (obr. 2). Antropomorfizmus je zretel’ne viditel’ný na plechových obrátených srdcovitých záveskoch, zobrazujúcich ženský dekolt s poprsím. Najevidentnejšie sa prejavuje na závesku z Dunaújvárosu a na zlatom závesku z bližšie neurčenej lokality v Mad’arsku (Jankovits 2017, 94, 95), kde sú jednoznačné zobrazenia ženských hrudných partií ozdobených náhrdelníkom. Zužujúci sa pásik stočený do očka predstavuje hlavu bez tváre, v prípade nálezu z neznámej lokality dotvorenú ešte ozdobou hlavy.

Tento tvar dopĺñajú aj drôtené okuliarovité závesky a liate obrátené srdcovité závesky. Nazvali sme ich gynekomastonomorfné (Jelinek - Valent 2019, 57). Okem kovového prevedenia sa objavujú vyrobené aj z keramiky alebo brezovej kôry (Vladár 1978, 79, obr. 49; Jelínek 2019).

Z ikonografického hladiska mimoriadne dôležitým nálezom sú tzv. hrebeňovité závesky (Jankovits 2008, 63; Kiss 2012, 103-106; Jankovits 2017, 76nn). Najdôležitejše sú antropomorfné hrebeňovité závesky, ktorých kompozícia vyzerá ako vel'mi štylizovaná postava v tzv. plechovom klobúku a sukničke/ zásterke s rukami v adoračnom geste (obr. 3). Týmto záveskom podobné zobrazenia poznáme aj z inkrustovanej a plastickej výzdoby keramiky viacerých, chronologicky nesúčasných kultúr (Jankovits 2008, 63, 62, obr. 6. 1: 15; Honti-Kiss 1999-2000, obr. 5: 1-3, 5; Banner 1956; Schreiber 1984, obr. 6: 1, 6: 4ab) alebo na ornitomorfných nádobách z Pákozdu a Veszprému (Guba - Szeverényi 2007, Fig. 5; Morteanu - Gogâltan 2015, 220, Pl. III: 3a-c). Plechové klobúky a sukničky/zásterky sa na-

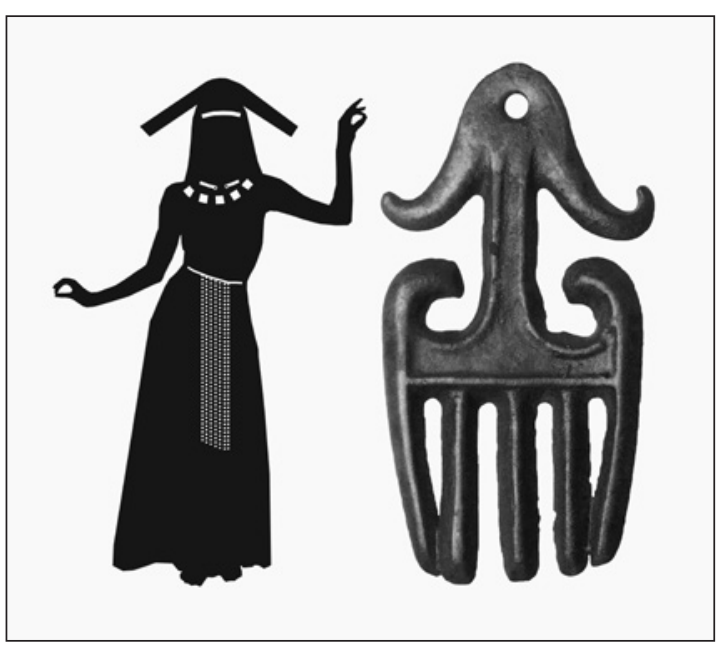

Obr. 3. Antropomorfný hrebeňovitý závesok a jeho metamorfóza.

Fig. 3. Anthropomorphic comb-like pendant and its metamorphosis. šli v hroboch žien s vysokým spoločenským postavením vo Franzhausene a v Nižnej Myšli (Neugebauer-Neugebauer 1996; Olexa - Nováček 2013). Nebude nepravdepodobné, že $\mathrm{v}$ antropomorfných hrebeňovitých záveskoch je vyjadrené stvárnenie ženského božstva, ktoré znázorňovali kňažky. Tzv. plechové klobúky sa síce našli len v materiálnej náplni unterwölblingskej kultúry, ich zobrazenia však vidíme vo viacerých kultúrach v Mad’arsku - od nagyrévskej po inkrustovanú. Paralely vidíme aj v glyptike východného Stredomoria (Jelínek - Valent 2019, 59n.). Je teda pravdepodobné, že bývali vyrobené aj z iného materiálu ako kovu. Nepriamym dokladom by mohol byt' objekt věteřovskej kultúry v Hodoniciach, v ktorom sa našla detská lebka so stopami, podl’a ktorých sa dá predpokladat' pokrývka hlavy pôsobiaca na lebku v dvoch priečnych súbežných pruhoch (Jelínek 2018, 38).

Paralelu so sukničkami/zásterkami je vidiet’ aj v novom náleze depotu z Hozelca - Dubiny (Hudáková - Hudák -Timura a kol. 2019, 26-39). Zo vzdialenejších oblastí sme ich zistili v krétskej glyptike a drobnej plastike a v nordickom okruhu doby bronzovej sa dochovali na bronzových soškách, ale aj unikátnom náleze strapcovej sukničky dievčat'a z Egtvedu (Jelinek - Valent 2019, 59).

K antropomorfným spodobeniam slnečného božstva patria závesky typu Včelince a Nagyhangos, (Jelínek - Valent 2019, 60). Širšie poňatou problematikou zobrazení slnečného božstva v dobe bronzovej sa venujeme na inom mieste (Valent-Jelinek, in prep.). 


\section{Praveké umenie ako súčast' kultúrneho systému}

V práci (Jelinek - Valent 2019, 48) sme sa zaoberali produktami pravekého umenia, resp. pravekého umeleckého remesla. Neponúkame jeho výklad, pretože chceme osvetlit' len niekol'ko jeho prvkov. Uspokojujeme sa s vysvetlením Lewisa Williamsa (2007), že praveké „umenie“ je výsledkom spoločenskej a nie osobnej činnosti. Umenie plní spoločenské účely, aj ked’s ním zaobchádzajú jednotlivci v sociálnych súvislostiach, aby dosiahli určité ciele. Mimo sociálny kontext sa mu nedá porozumiet' (Lewis-Williams 2007, 57). Pracujeme s konceptom, že starobronzové ikonografie zobrazujú prvky reality (v dnešnom zmysle slova), ale aj prvky pravekej „reality“, teda emické výstupy kultúry (ako symbolického systému), ideológie, produktov zmenených stavov vedomia apod. S emickým vysvetlením pravekého a súčasného primitívneho umenia prichádzajú nezávisle od nás aj autori z iných oborov (Rychlík 2014, 16; Dungel 2020).

Podla nášho názoru (Jelinek - Valent 2019, 66nn.) l’udia v staršej dobe bronzovej začlenili svoju evolučne vyvinutú schopnost' antropomorfizovat' a vytvárat' antropomorfné zobrazenia do svojej hmotnej kultúry. Nebola však pre nich natol'ko atraktívna, aby sa pokúšali rozvinút' ju umelecky, technologicky aj ekonomicky. Z archeologického hladiska boli v západnej časti Karpatskej kotliny tak málo známe, že J. Paulík $(1993,13)$ hovoril dokonca o tabuizácii Pudského zobrazenia v staršej dobe bronzovej na tomto území. Tu však vidím rozdiel, medzi (náboženským) zákazom a schopnost’ou zobrazenia realizovat'. Ostatne, tému tabuizácie môžeme presvedčivo opustit', lebo tunajší ludia, s výnimkou plastík l’udské zobrazenia vytvárali. Len iným spôsobom, ako archeológovia odchovaní klasickým umením, očakávali. Nízka miera antropomorfizácie môže súvisiet's funkčnou nevyhranenost’ou božstiev, ako to sledujeme v rannom védskom období, kde malá čast' božstiev vykazuje antropomorfné rysy. Mnohí bohovia predstavovali rôzne prírodné javy, astronomické objekty, abstraktné či etické princípy, deifikovanú obet’ apod. V textoch sú často zamieňané vlastnosti, mytologické činy i identita božstiev (Ondračka2004,135).

Z esteticko umeleckého hladiska nepredstavujú starobronzové ikonografie nič výnimočné. Geometrické zobrazenie l’udských postáv sa zo štýlového hl’adiska nevymyká podobným zobrazeniam, aké nachádzame v stredoeurópskom priestore v neolite alebo staršej dobe železnej (Šefćáková 2017; Kossack 1999, Abb. 86, 87).

Z technologického hladiska sú umelecké techniky na rovnakej úrovni ako v eneolite. Toto súvisí aj s ekonomickým hladiskom. Ludia v sledovanom kultúrnom okruhu skrátka neinvestovali čas a zdroje na rozvoj umeleckého remesla. Uspokojili sa hlavne s pomerne jednoduchými ozdobami tela (Novotný 2013, 124). S tepanými a rytými ozdobami a zbraňami sa stretávame relatívne vzácne. Napriek tomu ich tvorba nemohla nemat' isté grafomotorické zručnosti, ktoré ich výrobca mohol získat' len dlhodobým precvičovaním, pričom sa nemohol venovat' iným činnostiam.

Kto vyrábal prestížne ženské artefakty ostáva otvorené. Ale nález hrobu 3 z Geitzendorfu, v ktorom bola pochovaná žena so súpravou kamenných nástrojov slúžiacich na tepanie kovov (Lauermann-Pany-Kucera 2013) a pribúdajúce ženské hroby s kovotepeckým inventárom (Ernée - Langová et al. 2020,316) spochybňujú, že výrobcami tepanej plechovej industrie v staršej dobe bronzovej, ak vôbec, boli výlučne muži. Pri výraznej diferenciácii v pohrebnom ríte a hrobového inventára, môžeme usudzovat’ nielen na ženské a mužské artefakty aj v „živej“ kultúre, ale aj výrobcov a výrobkyne.

\section{Kde sú muži?}

Zistené zobrazenia považujem za ženské, teda za zobrazenie bohýň, ako som demonštroval vyššie. Naproti tomu nie je možné v hmotnej kultúre zachytit’ väčšie množstvo presvedčivých mužských zobrazení. Do úvahy prichádza snád' stratená plastika z Charvát (Tihelka 1962, 158, tab. XV: 4), rytina lovca na nádobe z hrobu v Mokrine (Giric 1971, T. XXXIV: GR. 110) a nami reinterpretovaná postava hromovládneho božstva na inkrustovanej nádobe z Budapešti - Panónskej ulice (Jelinek - Valent 2019, 63). To je oproti značnému množstvu ženských zobrazení skutočne nepomerne málo. Napriek tomu nám religionistické komparatívne analýzy indoeurópskych náboženstiev, a stredoeurópske starobronzové populácie už nepochybne boli indoeurópske (Jelinek - Valent 2019, s literatúrou), napovedajú, že mužské božstvá museli byt' nielen prítomné, ale museli mat' aj čelné miesto v lokálnych panteónoch. Prečo ich teda prakticky nezachytávame $\mathrm{v}$ hmotnej kultúre? 


\section{1. Mužské zobrazenia zo súdobých kultúrnych okruhov}

Z doby bronzovej poznáme zo súvekých kultúrnych okruhov aj zobrazenia mužov, či už ide o egejské a predovýchodné nástenné fresky alebo skalné umenie západoeurópskeho a severského okruhu. Tu si treba uvedomit', že $\mathrm{v}$ týchto prípadoch išlo o iný účel. Skalné a nástenné umenie malo bezpochyby viac funkcií, každopádne malo verejný charakter. Zobrazenia na predmetoch, najmä na šperkoch, reprezentovalo jednotlivca a jeho náboženské vyznanie a informovalo o jeho ochrane zobrazeným božstvom. Stále tu však ostáva otázka, chýbajúcich mužských/božských zobrazení. Prečo môžu chýbat' je otázkou dohadov. Je tu možnost’, že v strednej Európe, kde nemáme skalné umenie doložené, sa bud' nedochovalo, alebo sa skutočne nerealizovalo. Rovnako to mohlo byt's nástenným umením, rôzne scény mohli byt' vyobrazované (mal'ované alebo ryté) na stenách domov. Samozrejme, tieto možnosti bez dôkazov ostávajú len špekuláciou, aj ked’ pre vonkajšiu výzdobu domov náznaky máme (naposledy Ďuriš 2018). Je skôr pravdepodobné, že mužské božstvá ostávali skryté v abstraktnejších symboloch hmotnej kultúry, ako sú kančie kly, sekeromlaty a ich keramické napodobneniny a pod.

\section{Diskusia: spočíva odpoved’ vo výskume živých kultúr?}

V najstarších obdobiach praveku sa stretávame s obdobným javom zobrazovania ako v staršej dobe bronzovej. V drobnom mobilnom umení, ako sú mladopaleolitické a neolitické venuše, neporovnatelne prevládajú zobrazenia žien. Tento jav bol v minulosti mylne vyhodnotený ako prejav matriarchátu. Z týchto freudovských interpretácií, napr. pomocou sociologických analýz pohrebísk, už dnešná archeológia vyrástla, otázka však ostala: Prečo sú v pravekom mobilnom umení častejšie zobrazované ženy ako muži?

Pokúsil som sa na ňu sám sebe odpovedat' pomocou pomerne naivného prieskumu vo svojej facebookovej skupine. Pýtal som sa svojich priatelov, aké by zvolili antropomorfné tetovanie, ak by mali na výber len z dvoch možností (mužské/ženské). Napriek tomu, že „prieskum“ prebiehal v neanonymizovanej, pomerne homogénnej skupine s malým počtom respondentov, zdá sa že preukázal istý trend. Výsledky (graf 1) ukazujú, že muži tiahnu k mužským

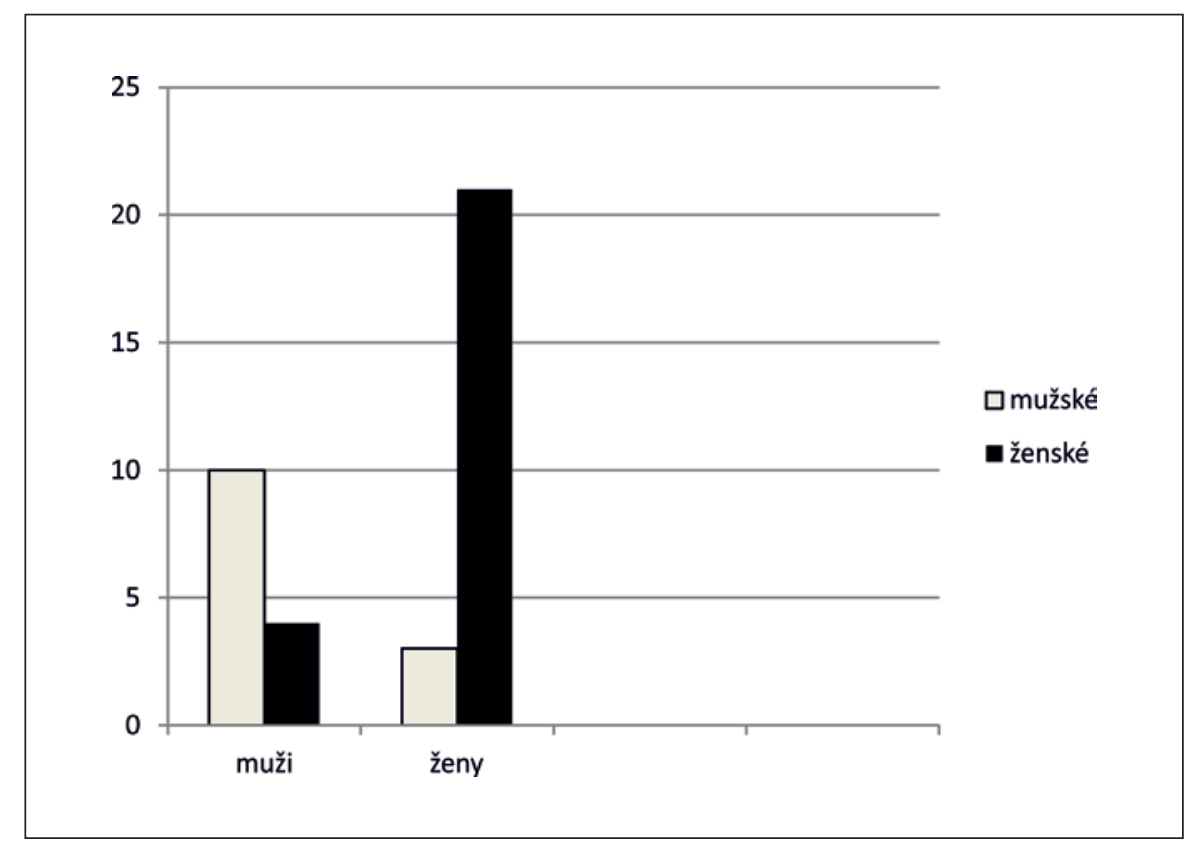

Graf 1. Pomer preferencií mužských a ženských tetovaní medzi mužskými a ženskými respondentmi z autorovej facebookovej skupiny priatel'ov.

Graph 1. Preferences of male and female tattoos among male and female respondents from wthe group of author's Facebook friends. 
zobrazeniam a ženy k ženským. Či však ide o nejakú psychologicko-biologickú vlastnost' ludského druhu ostáva otázkou.

Rovnako z autopsie mi je známy podobný jav pri detských kresbách, kde chlapci kreslia mužské a dievčatá ženské postavy (obr. 4), prípadne intuitívne nevyhranené postavičky stotožňujú s vlastným pohlavím. Samozrejme na potvrdenie týchto mojich predpokladov je potrebný ovela širš́i výskum, než som uviedol. Pre potvrdenie tejto pracovnej hypotézy by samozrejme boli potrebné d’alšie výskumy, psychologické aj kultúrno antropologické, sociobiologické a historiografické $\mathrm{v}$ najširšom zmysle, ak je $\mathrm{v}$ tomto prípade žiaduca holistická teória. Zatial' som však nezaregistroval štúdiu, ktorá by sa tomuto fenoménu venovala. $\mathrm{V}$ každom prípade ma poteší, ak ma erudovanejší čitatel’ na ňu upozorní.

\section{Záver}

Záver môjho špekulatívneho článku prináša viac otázok ako odpovedí. Prináša však poznatok, že tradičná archeológia si pri rekonštrukcii takých fenoménov ako je praveké náboženstvo sama svojimi metódami nevystačí. Problémom je, že ide o súčasti l'udskej kultúry, ktoré sa síce odrážajú v hmotnej kultúre, ktorú dokážeme „vykopat““, mieru tohto odrazu, jeho rozpoznanie a dešifrovanie však bez hlbších znalostí nie sme schopní definovat'. To si uvedomovali už postprocesualisti alebo v našich končinách Slavomil Vencl a jeho „archeologie nenalézaného“. Ja som si dovolil tento problém nazvat’ pascou pozitivizmu v skúmaní materiálnej kultúry. Príkladom toho sú práve „chýbajúce“ mužské božstvá v staršej dobe bronzovej. Zaiste nie je na základe dnešného poznania možné hovorit' o nejakom starobronzovom matriarcháte. K štúdiu fenoménov, ako sú praveké náboženstvá, sociálne vzt'ahy a pod. však nie je vhodné doteraz, žial', časté preberanie anachronických analógii z historických (u nás najčastejšie antických alebo dokonca biblických) kultúr, ale naopak interdisciplinárne štúdium prírodných (humánna etológia, neurológia), spoločenských (sociológia), humanitných (historiografia, religionistika, jazykoveda, experimentálna psychológia) a d’alších vied, s holistickým prístupom (kultúrna antropológia). Archeologické bádanie sa tým nesporne obohatí a prinesie, ako to už býva, okrem odpovedí aj nové otázky.

Poznámka: Táto práca bola podporovaná Agentúrou na podporu výskumu a vývoja na základe Zmluvy č. APVV-15-0491.

\section{Bibliografia}

Banner, J. 1956: Menschendarstellung auf einem Gefäß von Tószeg und die Frage der sogenannten Krötengefäße. Prähist. Zeitschr. 36, 244-254.

Dungel, J. 2020: Biologie umění. Praha 2020.

Duriš, J. 2018: Radzovce v období popolnicových polí. Architektonická rekonštrukcia stavieb na základe analýzy mazanice. Nitra.

Ernée, M. - Langová, M. et al. 2020: Mikulovice. Pohřebiště doby bronzové na Jantarové stezce. Památky archeologické 
Supplementum 21. Praha.

Girić, M. 1971: Mokrin. Nekropola ranog bronzanog doba. Washington - Kikinda - Beograd.

Guba, Sz: - Szeverényi, V. 2007: Bronze Age Bird Representations from the Carpathian Basin. Communicationes Archaeologicae Hungariae, 75-110.

Honti, Sz:-Kiss, V. 1999-2000: Neue Angabe zur Bewertung der Hortfunde von Typ Tolnanémedi. Acta Archaelogica Academiae Scientiarum Hungaricae 51, 71-96.

Hudáková, M. - Hudák, M. - Timura, J. a kol. 2019: Archeologický výskum v polohe Hozelec - Dubina. Spišská Nová Ves.

Jankovits, K. 2008: The Symbolism and the Wearing Fashion of Jewellery-pendants during the Bronze Age in Hungary. In: Anati, E. (ed.): Prehistoric Art and Ideology. British archeological Reports - International Series 1872. Oxford, 61-70.

Jankovits, K. 2017: Die bronzezeitlichen Anhänger in Ungarn. Budapest.

Jelinek, P. 2018: Hlavy v nádobách v mad’arovsko věteřovsko böheimkirchenskom komplexe. Čo nám môžu povedat'? Acta Musei Nationalis Pragae, Historia 72, č. 1-2, 37-45.

Jelinek, P. 2019: Birch Artifacts and Their Symbolism in the Otomani Culture. In: Fischl, K. P. - Kienlin, T. L. (eds.): Beyond Divides - The Otomani-Füzesabony Phenomen. Current Approaches to Settlement and Burial in the North-eastern Carpathian Basin and Adjacent Areas. Bonn, 71-81.

Jelinek, P. - Valent, D. 2019: Náboženské ikonografie v staršej dobe bronzovej. Zborník SNM 113 - Archeológia 29, $47-76$.

Kiss, V. 2012: Middle Bronze Age Encrusted Pottery in Western Hungary. Budapest.

Kossack, G. 1999: Religiöses Denken in dinglicher und bildlicher Überlieferung Alteuropas aus der Spätbronze- und frühen Eisenzeit (9.-6. Jahrhundert v. Ch. Geb.). München.

Lauermann, E. - Pany-Kucera, D. 2013: Grab 3 aus dem Aunjetitzer Gräberfeld von Geisendorf. Das Erste Nachweis einer Metallverarbeiterin in der Frühbronzezeit Niederösterreichs. Slovenská Archeológia 61-1, 93-106.

Leeb, A. 1994: Das frühbronzezeitliche Gräberfeld von Melk/Spielberg - Flur Pielamünd, Niederösterreich. Zalai Múzeum 5, 113-130.

Lewis-Williams, D. 2007: Mysl v jeskyni. Vědomí a původ umění. Praha.

Morteanu, R. - Gogâltan, F. 2015: O protomă ornitomorfă din epoca bronzului de la Satu Mare, jud. Arad. In: Forțiu, S. - Stavilă, A. (eds.): Arheovest III - in memoriam Florin Medeleț - Interdisciplinaritate în Arheologie şi Istorie. Szeged, 205-228.

Novotný, L'. 2013: Počiatky pravekého umenia na Slovensku. Martin.

Neugebauer, Ch. - Nengebauer, J. W. 1996: Kopfzierden aus Frauengräbern der Nekropole I von Franzhausen. In: Kovács, T. (Hrsg.): Studien zur Metallindustrie im Karpatenbecken und den benachtbaren Regionen. Festschrift für 
Amália Mozsolics zum 85. Geburtstag. Budapest, 103-124.

Olexa, L. - Nováček, T. 2013: Pohrebisko zo staršej doby bronzovej v Nižnej Myšli. Katalóg I (hroby 1 - 310). Nitra.

Ondračka, L. 2004: Pojetí božství v Indii. In: Chlup, R. (red.): Bůh a bohové. Pojetí božství v náboženských tradicích světa. Praha, 131-159.

Paulike, J. 1993: Bronzom kované dejiny. Bratislava.

Rycblike, M. 2014: Antropologie umění: Etnoestetické studie s důrazem na preliterární a mimoevropské kultúry. Dizertačná práca. Ústav etnologie FF UK v Praze. Praha.

Scbreiber,R. 1984: Szimbolikus ábrázolások korabronzkori edényeken. Arch. Ért. 111, 3-28.

Šefćáková, A. 2017: Magické praveké kresby v jaskyni Domica v Slovenskom krase. Zborník SNM 111 - Archeológia $27,15-42$.

Tihelka, K. 1962: Moravský věteřovský typ. II. část (materiál). Štud. Zvesti AÚ SAV 8.

Valent, D. - Jelinek, P., in prep.: Séhul a jej podoby v hmotnej kultúre doby bronzovej.

Vladár, J. 1978: Umenie dávnovekého Spiša. Bratislava.

\section{Summary}

In the paper I briefly deal with few questions that emerged during the study of religious iconographies of the Early Bronze Age. Mostly, with the exception of standalone sculpture, they are depicted on metal headbands, tiaras and so-called metal hats (Fig. 1). Another group consists of gynecomastonomorphic and anthropomorphic pendants, which I deem to be the depictions of goddesses (Fig. 2, 3).

On the other hand, it is not possible to catch in the material culture larger amount of convincing male depictions. Despite this, the comparative analyses of Indo-European religions, Central European Early Bronze Age populations were undoubtedly Indo-European, indicate that male deities had to be not only present, but they had to head the local pantheons. Then why are they so hard to catch in the material culture?

We know the depictions of men from contemporary cultural areas, the Aegean of Near East wall frescoes or rock art of the Eastern European or Nordic region. Here we need to realize that in these cases the purpose was different. Rock and wall art had no doubt more functions, it was also public. Depictions on objects, mostly jewels, represented an individual person and their religious preferences and informed about their protection by depicted deity. However, the question of missing male/divine depictions remains. We can only guess why they are missing. Probably the male deities remained hidden in more abstract symbols of material culture, such as boar tusks, battle-axes and their ceramic imitations etc.

As a demonstration of gender ways of depiction I performed a survey (rather naive, I realize its weaknesses) in my Facebook group. I asked my friends what anthropomorphic tattoo they would choose if they had only two options (male/female). There seems to be a trend. The results (Graph 1) suggest that men tend to choose male and women female tattoos. The same trend appears with child's drawings, boys tend to draw male and girls female figures (Fig. 4). Of course to confirm these suggestions we need much wider survey. To confirm this working hypothesis we would need another surveys, psychological as well as from the area of cultural anthropology. However, by now I have not noticed a study of this phenomenon. In any case I would be pleased if a more knowledgeable reader enlighted me. 
We have more questions than answers. But they are bringing us the knowledge that the methods of traditional archaeology are not enough when it comes to the reconstruction of such phenomenon like prehistoric religion. The problem is that we are talking about the parts of human culture that are reflected in material culture which can be „excavated“, however we are not capable to understand the degree of this reflection, its recognition and decoding without wider knowledge. I would call this problem „a trap of positivism in the research of material culture“. The examples are „missing“ male deities in the Early Bronze Age. Of course we cannot speak about the matriarchy of the Early Bronze Age just on the basis of our current state of knowledge. I see the way out of this „trap“ in an interdisciplinary approach, together with human ethology, experimental psychology, cultural anthropology and other scientific fields. 